\title{
THE INFLUENCE OF GLOBALIZATION PROCESSES ON THE INNOVATIVE DEVELOPMENT OF THE FOOD INDUSTRY OF UKRAINE IN THE PHASES OF BUSINESS CYCLES
}

\author{
A. V. Balian ${ }^{1}$, M. P. Sychevskyi ${ }^{2}$, O. V. Kovalenko ${ }^{2}$, L. O. Yashchenko ${ }^{2}$, S. B. Verbytskyi ${ }^{2}$ \\ ${ }^{1}$ National Academy of Agrarian Sciences, 9, Omelianovych-Pavlenko Str., Kyiv, 01010, Ukraine \\ ${ }^{2}$ Institute of Food Resources of the National Academy of Agrarian Sciences of Ukraine \\ 4a, Yevhen Sverstiuk Str., Kyiv, 02002, Ukraine
}

E-mail: sychevskiy@ipr.net.ua; okovalenko0960@gmail.com; lud_ya@ukr.net; verb@ipr.net.ua

Received September 26, 2019 / Received October 18, 2019 / Accepted November 19, 2019

\begin{abstract}
Aim. One of the important problems in the development of the food industry in Ukraine is the influence of globalization processes, accompanied by cyclical development of the economy. The cycles are manifested in periodic ups and downs of the business climate, taking into account the influence of various factors (climate change, risks in agricultural production, legislative changes, etc.), i.e. when the economy seeks to find equilibrium. Therefore, the identification of fluctuations in economic activity and, accordingly, changes in market conditions that arise as a reaction to the action of well-defined, predictable factors of the market environment are relevant and necessary. The purpose of the article is to reveal the influence of globalization processes and economic cyclicality on the innovative development of the food industry in Ukraine, to identify the phases of business cycles, to determine the criteria for the effective functioning of individual food industry sectors during periods of crisis and depression in order to develop effective tools for leveling and smoothing their consequences at different levels of management. Methods. Based on the application of classical and modern methods for assessing economic cycles, we developed a methodological approach to justifying the phases of the business cycle and identifying the development specificities of individual sectors of the food industry of Ukraine (meat processing, milk processing, baking, sugar production) in these phases. In the authors' algorithm, at the appropriate stages of the study, the following methods were applied: factor analysis - to calculate the indicator of the business climate; smoothing time series - to identify individual phases of the business cycle; average values of growth rates - to summarize the characteristics of the phases of the business cycle and identify the characteristics of the development of food industry sectors of Ukraine in these phases. The primary data for the calculations were the data of global and national statistics. Results. It has been established that the consequences of the impact of globalization on the development of the food industry of Ukraine since the beginning of the new millennium are: changes in the industrial structure; its formation under the influence of an external market, where raw materials and primary processing products are most in demand; accelerated growth in consumer prices for food products, which does not correlate with real incomes of the population; expanding the monopolization of food markets; the imbalance of supply and demand, which leads to differences in the development of economic phenomena, in particular - in the innovative development of the food industry, etc. The study showed that the development of individual sectors of the food industry is affected by the cyclical development of the national economy. The periods of the business cycle phases for the Ukrainian economy (from 2002 to mid-2019) and their impact on the activity of the food industry are determined. It was established that during this period the Ukrainian economy went through 4 business cycles with five major downturns and peaks in economic activity. It was revealed that a sign of its development is the presence of separate business cycles in which there is no depression phase. Conclusions. The assessment of the intensity of the development of the food industry sectors during the phases of business cycles gives grounds for the justification of their slower innovative development. The main reasons for this phenomenon in the food industry are as follows: imbalance in supply and demand for goods; low purchasing power of the population; investing significant amounts of finances in increasing production volumes, and not in innovative development, inefficient pricing policy. The methodological approach proposed in the article, based on the identified signs of the phases of the business cycle, makes it possible to justify the problem periods of the food industry in the short term, as current problems significantly affect the implementation of long-term plans. This confirms the feasibility of applying the proposed methodological approach in further research.
\end{abstract}

Keywords: globalization, food industry, cyclicality, business cycles, innovative development. DOI: 


\section{INTRODUCTION}

The monitoring of the current state of the food system demonstrates that at the beginning of the XXI century the development of the food industry acquired a new characteristic: globalization has become the most relevant way of its functioning and development and at the same time, a new stage of economic life integration. This state of global economy, especially in conditions of economic crisis, forced the countries to adjust their plants of economic development. At present, long-term tendencies of the global development, creating risks for the food sector in Ukraine and globally, are as follows: fiercer competition for limited natural resources (energy, water) and food; increased urbanization; increased number of the population and their aging, global climate change; terrorism and migration crisis; social inequality and rise in unemployment; integration of large business and monopolization of food markets; trickling of the capital down from the developed countries to the developing countries; reduced rates of economy growth up to $1.5-2 \%$ per annum, etc. $[1,2]$.

In many studies of several recent decades, the scientists relate these conditions to the innovative changes in business, whose activity dynamics is decreasing constantly and causing the decrease in performance. In the opinion of foreign economists, first and foremost, this state is conditioned by the fact that large corporate business (with considerable capital and market shares) is not always interested in improving industrial processes using innovations, as any changes always present risks $[1,2]$. At the same time, the results of polls indicate that the efficiency of companies, manufacturing food products, is enhanced due to technological innovations: of food (77.8 \% of respondents); of packing (57.1\%); of processes $(53.2 \%)$ [3-5].

The assessments, made using the data of the State Statistics Service of Ukraine, demonstrate current tendencies to slower rates of performance increase in the country's economy and, thus, innovative activity. If during 2001-2010 the performance increased by $4.4 \%$ per annum on average, during 2011-2018 it increased by $1.7 \%$. The annual average rate of performance increase in food industry during 2011-2018 was 3.4\%. At the same time, the innovative development of food industry is rather slow, as the business environment in the country is characterized by instability and infrastructure problems. A share of innovative products in the total volume of sold products of food industry dropped from $3.3 \%$ in 2011 to $0.82 \%$ in 2017 .
A relevant globalization process, having a considerable impact on the innovative development of food industry, is the implementation of the Association Agreement between the European Union and Ukraine, aimed at creating conditions for extension of trade and economic relations and ensuring gradual integration of Ukraine into the domestic market of the EU, including the creation of free trade zones. At the same time, the experience of some countries demonstrates that the expected outcome of such agreements is mainly positive, but the burden on particular agrofood sectors may cause difficulties in the domestic market structures $[6,7]$.

It is also noteworthy that recently the studies on globalization processes in different subject areas are more frequently related to the cyclicality of economy development (or economic cyclicality), when sharp differences in the development of common economic phenomena are explained by the change in proportions or loss of balance between the key indices in ecological, demographic, social, political and other spheres of influence $[2,8,9]$. Therefore, in our opinion, the signs of economic cyclicality should be considered while assessing the specificities of innovative development of food industry. In this sense, noteworthy are scientific achievements of one of the founders of the economic cyclicality theory - M. Kondratiev [10]. His studies and conclusions, on conditions of absence of any software, were based on empirical analysis of a great number of macroeconomic indices of different countries in long time periods.

Long fluctuations were first noted while studying the price dynamics. Walt Whitman Rostow became one of the followers of this direction of studies. This aspect of the shallow water theory was highlighted in his book Why the Poor Get Richer and the Rich Slow Down [11]. The author was trying to prove that changes in demand and supply of raw materials and food products, caused by the change in prices for them, influence the innovative activity, which defines the sequence of leading sectors of industry and depends on them. In addition, a considerable impact on innovative activity is made by demographic factors, house construction, change in the composition of labor force. These three moments are closely related to each other. Isolating and uniting them, W. Rostow tried to integrate three directions in his shallow water theory: agrarian-pricing; innovativeinvesting; demographic.

In the opinion of specialists, rather a substantiated statistical analysis of business cycles was described 
in the work of F. Burns, W. Mitchell [8], which presents the methods of assessing and predicting economy development in particular developed countries based on cyclic fluctuations and determination of the dates of turning points. Since then, the forecast of future via the analysis of cyclicality obtained its relevant place in the macroeconomic analysis. Among recent works in this direction of studies, noteworthy are the works of foreign and domestic scientists: M. Pugachova [9], A. Pestova [12], P. Vlag, K. Zeelenberg, etc. [13]. The aim of the aforementioned authors' studies was to create a model (digital, non-numerical, graphic), capable of forecasting the macroeconomic crisis occurrence in the country beforehand and the ways out of it. However, the specificities of the innovative development of some sectors of food industry in conditions of globalization require new complex studies [14]. We have used the concept of the dynamic system with formulated problems of the sensitivity of industrial food systems and presented definition of their resistance as a capability of counteracting the failures, which may cause disruptions in food supply [15-17].

The purpose of the study is to disclose the impact of globalization processes and economic cyclicality on the innovative development of the food industry in Ukraine (using the example of meat processing, milk processing, baking and sugar industries), to determine the phases of business cycles, to determine the criteria for the effective functioning of specific sectors of the food industry during the periods of crisis and depression to ensure the possibility of further smoothing of their consequences.

\section{MATERIALS AND METHODS}

Based on the application of classical and modern methods to assess economic cycles, we developed a methodological approach to justifying the phases of the business cycle and identifying the development signs of individual sectors of the food industry of Ukraine (meat processing, milk processing, baking, sugar production) in these phases. In the authors' algorithm, at the appropriate stages of the study, the following methods were applied: factor analysis - to calculate the indicator of the business climate; smoothing time series - to identify individual phases of the business cycle; average values of growth rates - to summarize the characteristics of the phases of the business cycle and identify the characteristics of the development of food industry sectors of Ukraine in determination phases. The primary data for the calculations were the data of global and national statistics.

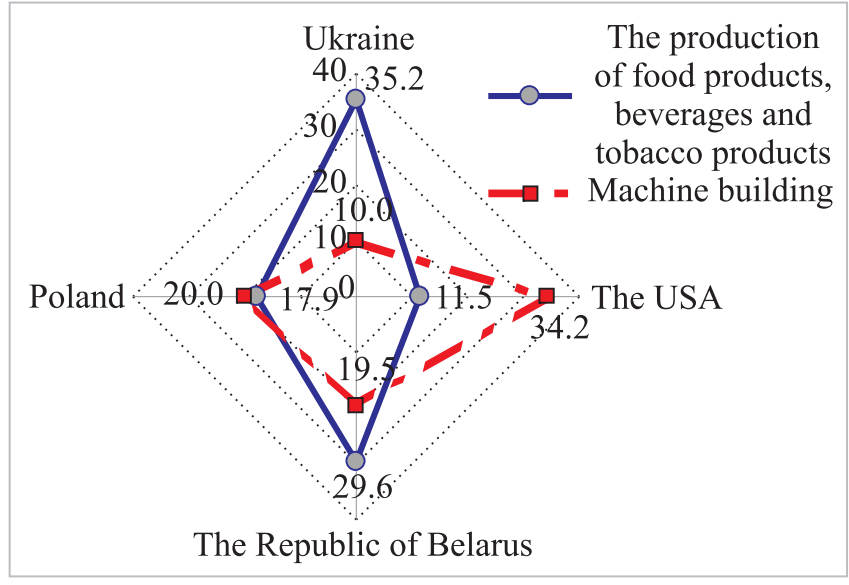

Fig. 1. The comparison of the production shares of food industry and machine building in the structure of the processing industry in Ukraine and some other countries in 2016, \% Source: developed using the data of the World Bank, Belstat (the Republic of Belarus) and the State Statistics Service of Ukraine

The main results of the study. At present the most significant economic and financial impact on global economy is made by the USA, the EU member-states, China. At the same time, as the tempo of economic growth is gradually slowing down in many countries of the world, structural disproportions between economic indices in the developed and weakly developed countries as well as inside the countries themselves change all the time. [18]. It should be noted that the share of Ukraine in the global GDP for 2010-2018 fluctuates within the range of $0.15 \div 0.21 \%$.

Ukraine's economy is notable for most signs, remarkable for the economic systems of developing countries: absence of proper transparency and weak competition, caused by delayed and incomplete reforms and thus a low level of development of the innovative system [19]. In addition, in conditions of establishing global market, the country witnesses the changes in the sectorwise structure of the industry. However, the vector of these changes is usually aimed at low technology and material production, which are not capable of ensuring extended restoration of the main measures and modern modernization of industry sectors. For instance, the comparison of the sector-wise structure of processing industry in Ukraine and the developed countries demonstrates absolutely contrary shares of food industry and machine building (Fig. 1). The group of reference countries, selected for the comparative analysis of the structure of the processing industry, includes the USA as the most developed and powerful country, impacting the global economy; Poland - a country with basic 


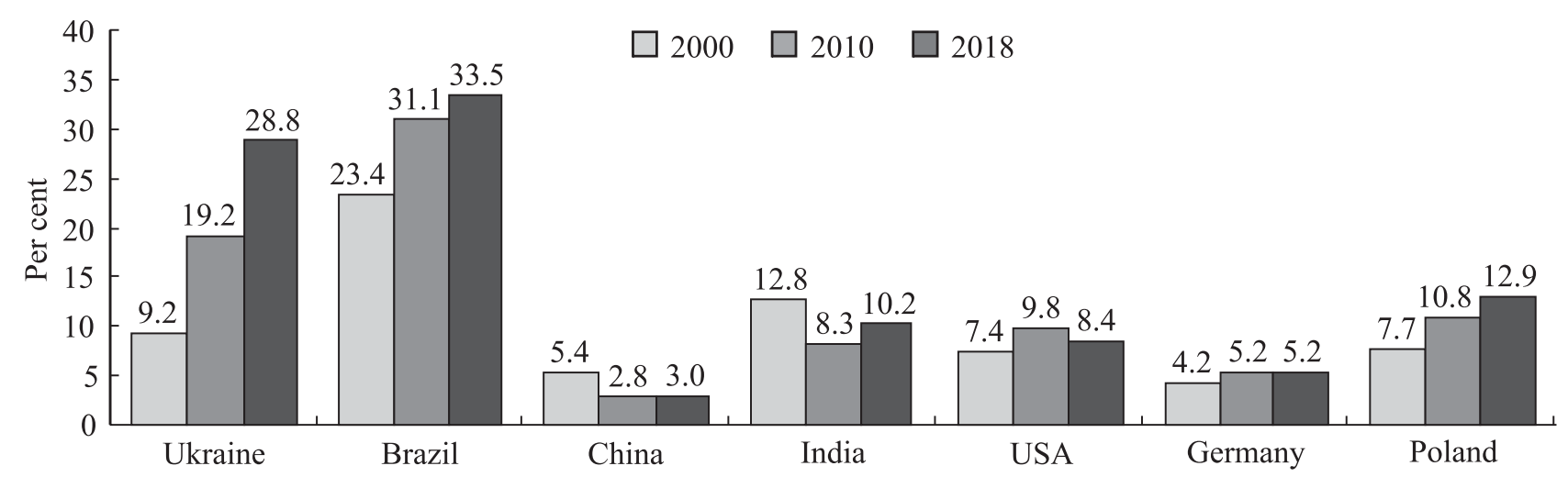

Fig. 2. The export of food products in the cumulative volume of export in terms of countries, \%. Source: developed using the data of the World Bank

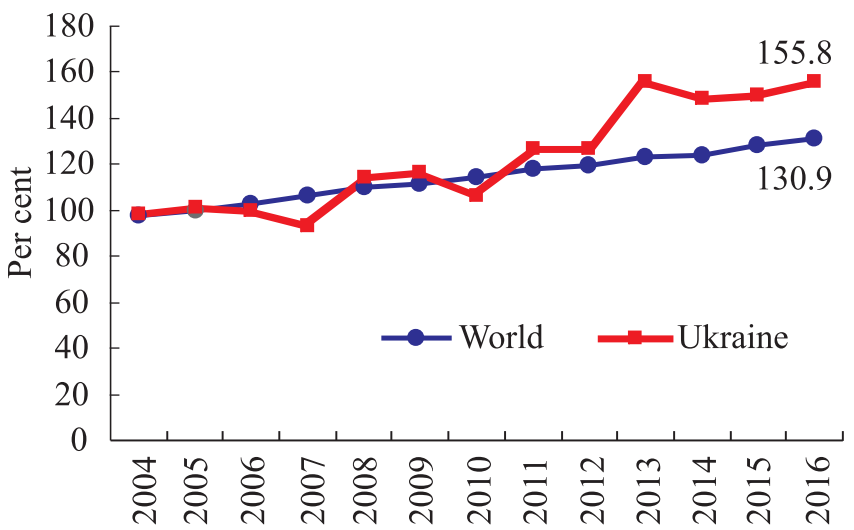

Fig. 3. The gain in the production of food products in Ukraine and in the world, \%. Source: summarized using the data of the World Bank (https://data.worldbank.org/indicator)

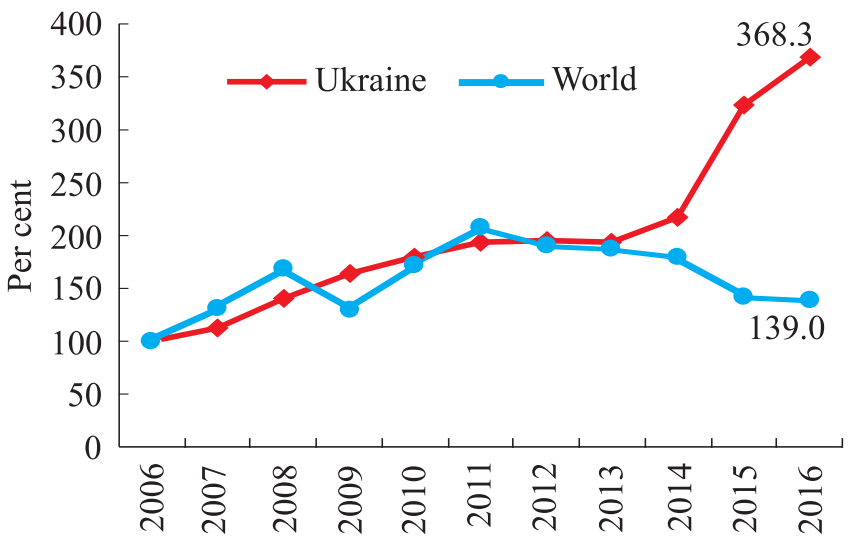

Fig. 4. The rise (drop) in consumer prices for food products in Ukraine and in the world, \% (2006 = $100 \%)$. Source: summarized using the data of the World Bank (https://data. worldbank.org/indicator)

economy structure, similar to Ukraine, a neighboring country with common historical periods of development, similar territorial-climatic conditions and population structure; Belarus - a neighboring country, a former Soviet republic, which started building an independent country at the same time Ukraine did, and has similar food traditions.

According to the recent data of the World Bank, in 2016 the contribution of machine building, which should be the core of scientific-technical and socialeconomic progress, in the structure of Ukraine's processing industry was $10.0 \%$ whereas the share of food production amounted to $35.2 \%$. At the same time, the share of machine building in the structure of the processing industry in the USA, Belarus and Poland exceeded Ukraine's index more than twice.

Inefficient structure of industrial production of food industry is considerably formed by the demand of the external market, where raw materials and primary processing products are usually most required. For instance, in 2017-2018 marketing year (September 01, 2017 - August 31, 2018) the global export of sunflower oil was 9.7 million tons, out of which 5.34 million tons of oil of primary processing were from Ukraine [20].

In 2000-2018 Ukraine's share of food products export in the cumulative export volume increased more than three times, whereas in most leading countries the increase did not exceed $65 \%$, and in the greatest economies of Asia (China and India) this share was even reduced (Fig. 2). While supporting low technology (material) export, the country loses both the added value and human and industrial potential.

At present the activities of low technology level, which, according to the international classification, include food industry, develop somewhat slower, but with some acceleration. Evidently, the total gain in the production of food products in Ukraine since 2013 has exceeded the global values (Fig. 3). Compared against 


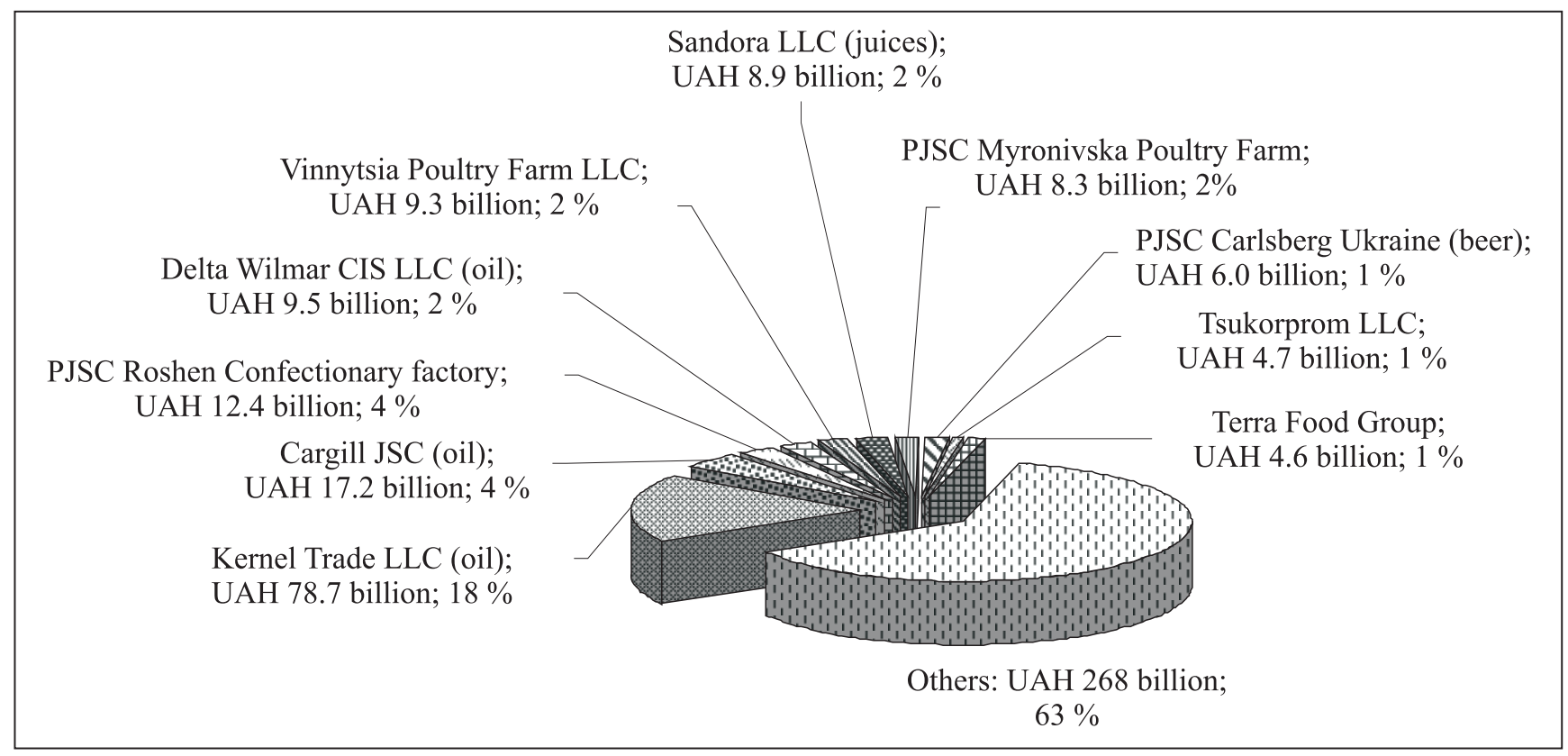

Fig. 5. Top 10 companies in the structure of sold food products. Source: summarized using the data of the State Statistics Service of Ukraine and TOP-100. The ratings of the largest. (2018)

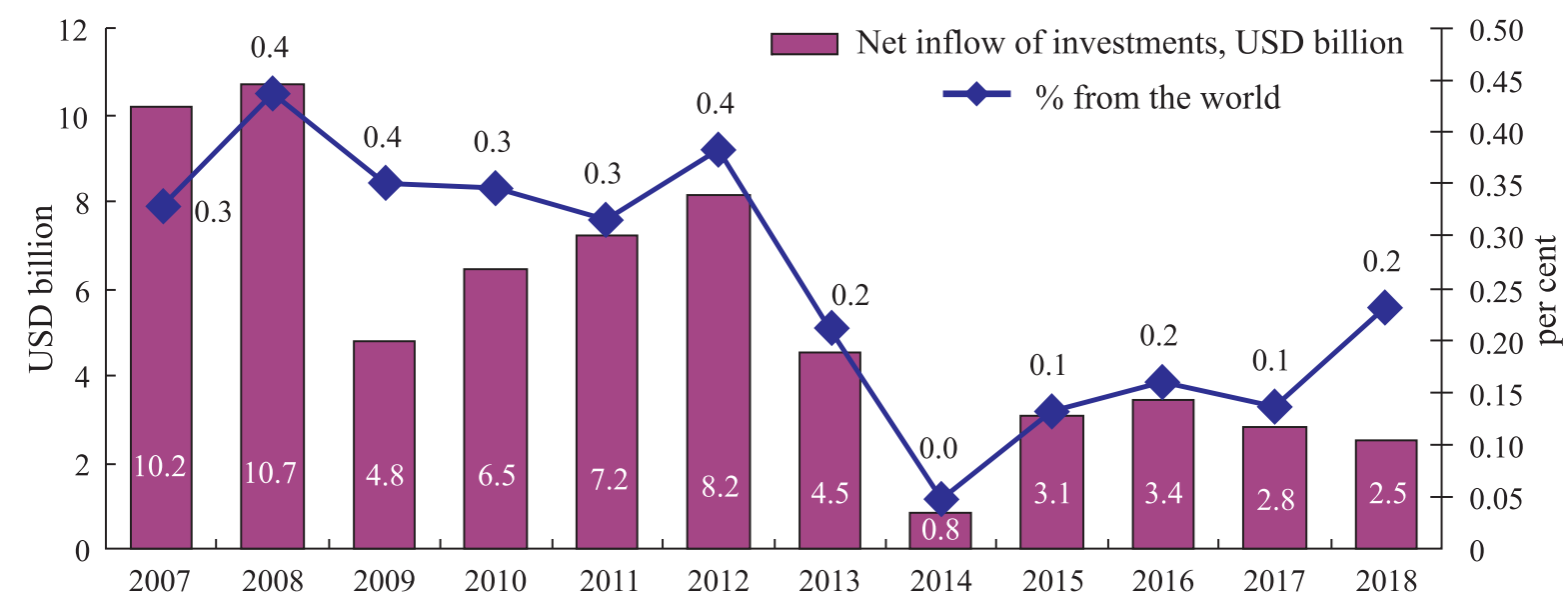

Fig. 6. The net inflow of foreign investments into Ukraine's economy, USD billion. Source: developed using the data of the World Bank. URL: https://data.worldbank.org/indicator/BX.KLT.DINV.CD.WD

the average global dynamics of the development of food production, in recent years the index of acceleration has amounted to $27.6 \%$.

The risk of structural dynamics of this period became accelerated rise in consumer prices for food products, which does not correlate with real income of the population (Fig. 4).

Some worries are caused by the increase in the scales of monopolization of food markets and the number of foreign companies, producing food products in Ukraine, which "come" to the domestic market with their well-established technologies and are not always interested in improving industrial processes using innovations. Thus, the share of the ten largest companies in food production in the volume of sold products of food industry in 2017 (UAH 427.6 billion) reached $37 \%$ (Fig. 5) and their cumulative income amounted to UAH 159.6 billion.

The owners of about half of the listed companies are non-residents of Ukraine [21].

At the same time, it should be noted that foreign investing in Ukraine was the main source of innovative updating of material-and-technical and technological foundation of food industry [3]. 
BALIAN et al.

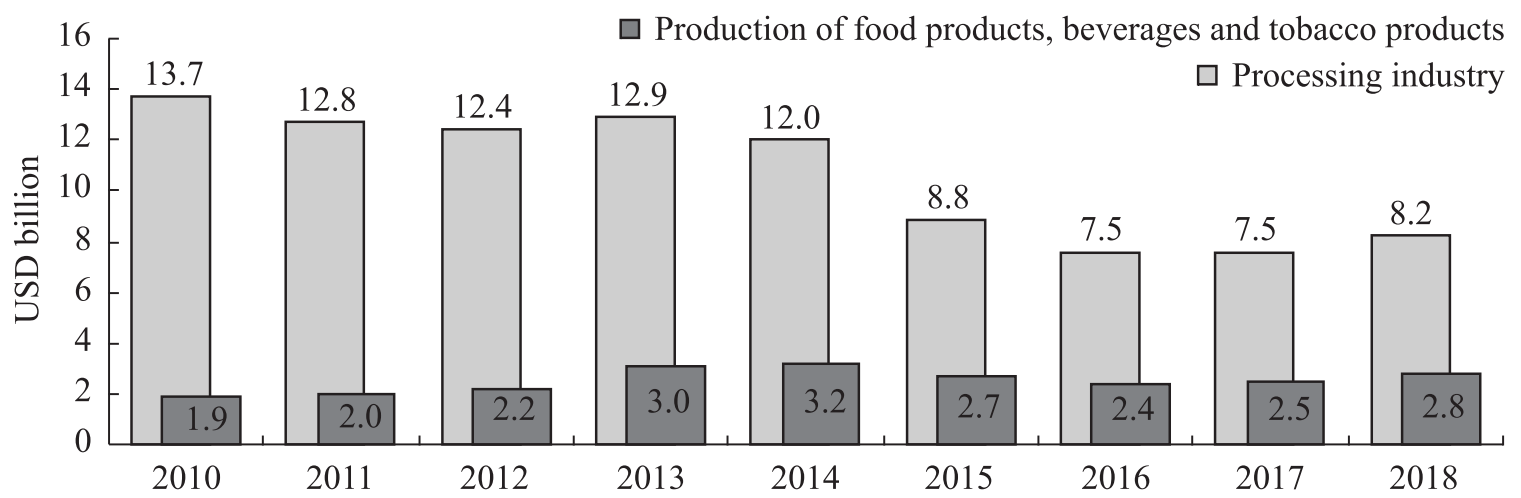

Fig. 7. The stock capital (direct foreign investments), flowing into processing and food industry of Ukraine, USD billion. Source: developed using the data of the State Statistics Service of Ukraine

Since 2007 global volumes of foreign investments had a tendency to decreasing - from USD 3.1 trillion (2007) to USD 1.1 trillion (2018). Therefore, the inflow of investments into Ukraine and their share in the global volume decreased from 0.4 to $0.2 \%$ (Fig. 6).

Regardless of the decrease in the investment volumes into Ukraine, food industry in 2014-2018 remained the main industry among the sectors of processing industry, into which foreign investments flew most actively due to their rapid time to value. The cumulative inflows into food industry in 2018 were USD 2.8 billion or $34 \%$ in the structure of the processing industry (Fig. 7).

However, it should be noted that the issue of determining a safe share of foreign capital concentration remains to be properly assessed, and domestic producers are insufficiently protected (especially small business) from its competition.

According to the data of the State Statistics Service, every year about $30 \%$ of food industry enterprises operate in the red. One of the reasons for this phenomenon is imbalance between supply and demand which causes the cyclicality of economy development in the shortterm period, i.e. it forms business cycles. Therefore, the methodological approach, suggested by us, will give a possibility to identify and forecast the phases of business cycles with relevant recommendations for sectors of food industry regarding the increase in their innovative activity and available instruments of regulating economic processes.

In most countries the studies on the cyclicality of economy development are conducted using the indicators of business expectations, calculated using the research of business activity of enterprises [22].

In the presented study, the phases of the business cycle were determined based on one of the indicators of business expectations - the indicator of the business climate, which actually is a result of the summarizing estimate, conducted using the factor analysis in the IBM SPSS Statistics program. Here the method of principal component analysis was used for seasonally adjusted values of the production volume balance for previous and subsequent three months, current domestic and foreign demand (order) for the production of products, current stock volumes of ready products. As a result, one factor united several variables, which had dense correlation $[22,23]$.

To calculate the indicator of business climate $\left(I_{B C}\right)$, there was a search for such linear combination of standardized variables $\widetilde{X}_{1 t}, \widetilde{X}_{2 t}, \widetilde{X}_{3 t}, \widetilde{X}_{4 t}, \widetilde{X}_{5 t}$, which would satisfy the condition [22]:

$I_{B C t}=a_{1} \cdot \tilde{X}_{1 t}+a_{2} \cdot \tilde{X}_{2 t}+a_{3} \cdot \tilde{X}_{3 t}+a_{4} \cdot \tilde{X}_{4 t}+a_{5} \cdot \tilde{X}_{5 t}$,

where $a_{i}$ is defined using the matrix of assessment ratios; $i=1, \ldots, 5$;

$$
\begin{gathered}
\tilde{X}_{j t}=\frac{X_{j t}-\bar{X}_{j}}{S_{j}}, \\
\overline{X_{j}}=\frac{1}{T^{\prime}} \sum_{t=1}^{T^{\prime}} X_{j t}, \\
S_{j}=\sqrt{\frac{1}{T^{\prime}-1} \cdot \sum_{t=1}^{T^{\prime}}\left(X_{j t}-\bar{X} j\right)^{2},}
\end{gathered}
$$

where $j=1, \ldots, 5 ; T^{\prime}-$ length of time series (in our case - number of quarters); indicators $X$ - seasonally adjusted values of balances, $\%: X_{1 t}-$ demand for products (orders); $X_{2 t}$ - changes in the production of products within the following 3 months; $X_{3 t}$ - stock of products; $X_{4 t}$ - changes in production of products for previous 3 months; $X_{5 t}$ - export of products; $\widetilde{X}_{1 t}-$ standardized value of demand for products; $\widetilde{X}_{2 t}-$ standardized value of 


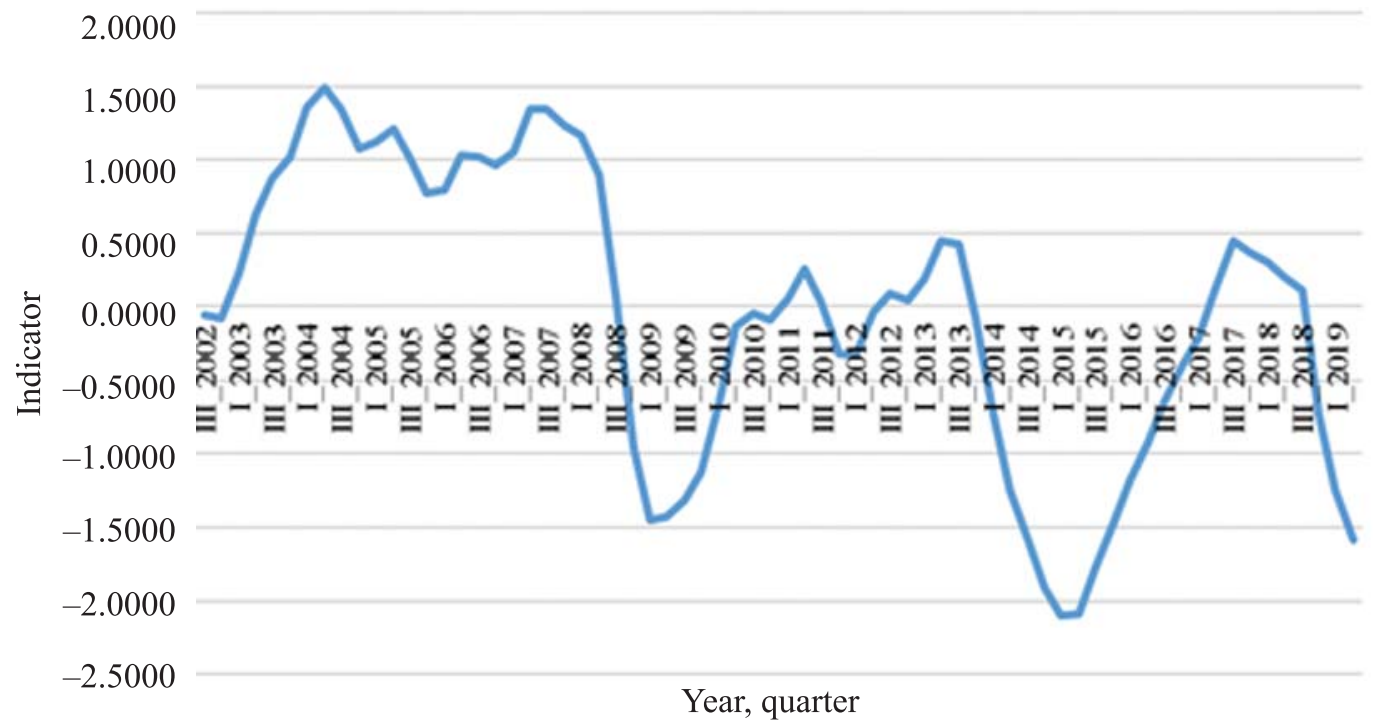

Fig. 8. The indicator of business climate, characterizing the cyclicality of Ukraine's economy development in quarter 3 of 2002 - quarter 2 of 2019. Source: calculated using the data of the State Statistics Service

changes in the production of products in the following 3 months; $\widetilde{X}_{3 t}$ - standardized value of the stock of pro ducts; $\widetilde{X}_{4 t}-$ standardized value of changes in the production of products within the previous 3 months; $\widetilde{X}_{5 t}$ - standardized value of export. Seasonally adjusted values of balances were determined based on the polls regarding the business activity of enterprises (as a difference between the share of positive and negative responses).

The assessment of the business climate indicator for Ukrainian economy was conducted within the period from quarter 3 of 2002 till quarter 2 of 2019. The correlation coefficients and complete dispersion demonstrated the reasonability of uniting the initial indicators into the summarizing indicator of business climate. As standardized values of the indicators were used to calculate the business climate indicator, the assessed values of the indicator change from the highest downturn in the investigated period (quarter 1 of 2015) to the highest efficiency (quarter 2 of 2004). The calculations were made according to the data of the State Statistics Service of Ukraine (Fig. 8).

The chart (Fig. 8) demonstrates that during quarter 3 of 2002 - quarter 2 of 2019 Ukrainian economy passed 4 business cycles and 5 times reached its "bottom" and peaks of innovative activity. Here the first business cycle (quarter 3 of 2002 - quarter 4 of 2008) contained only the phases of economic crisis; revival and takeoff. The phase of depression was absent. The reason for "fall-out" of the depression phase could have been, for instance, the balance between demand and supply, activation of innovative activity, etc.
The chart of The Business Cycle Study was built based on the values of the business climate indicator (Fig. 9), which is used to determine the phases of business cycles and includes the following stages:

1. Correcting the business climate indicator to separate business cycles using the Hodrick-Prescott filter [22].

2. The assessment of the values of absolute gains in the business climate indicator.

3. Building the chart of The Business Cycle Study in Excel.

The data of the study are based on the implementation of the following conditions:

1) ensuring "the accuracy of adjusting the curve" via minimization of the sum of squared deviations of the corrected time series from the initial series:

$$
\sum_{t=1}^{T^{\prime}}\left(I_{B C t}-\hat{I}_{B C t}\right)^{2} \rightarrow \min
$$

where $\hat{I}_{B C t}$ - corrected indicator of the business climate at a moment of time $t$;

2) ensuring "the degree of trend smoothness" for the corrected time series:

$$
\sum_{t=2}^{T^{\prime}-1}\left(\left(\hat{I}_{B C t+1}-\widehat{I}_{B C t}\right)-\left(\hat{I}_{B C t}-\hat{I}_{B C t-1}\right)\right)^{2} \rightarrow \min
$$

where $\hat{I}_{B C+I}$ - corrected indicator of the business climate at a moment of time $t+1 ; \hat{I}_{B C t-1}$ - corrected indicator of the business climate at a moment of time $t-1$. 


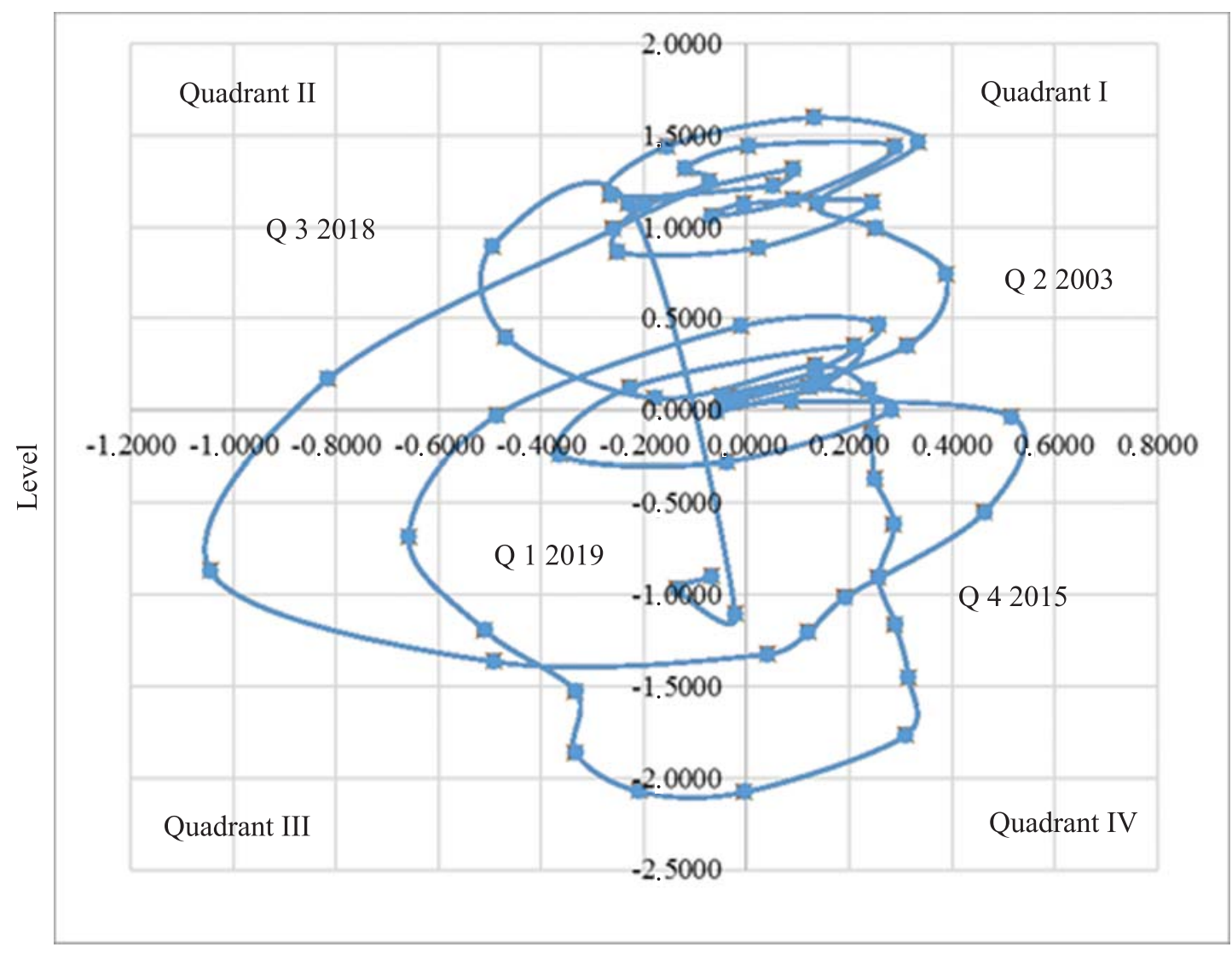

Quarter to quarter

Fig. 9. Chart of The Business Cycle Study. Source: Built on the basis of the business climate indicator using the data of the State Statistics Service of Ukraine

The correction of a series envisages setting the parameter $>0$, which demonstrates the degree of the "smoothness" of the series. The higher value of is, the "smoother" series we obtain. At low values of the assessment of the corrected series practically coincides with the initial series, and at very high values - approximates a usual linear trend. The value is set by the method of selection. The practice demonstrates that the lower $\lambda$ is, the closer the corrected values are to actual ones.

The horizontal axis of the chart ("level", Fig. 9) is the value of the corrected indicator of the business climate, and the vertical axis ("quarter to quarter") estimated values of the absolute gains of the corrected indicator. The flow of indices on the chart occurs counterclockwise through chart quadrants. Each point on a chart (the value of the indicator) corresponds to a specific date in the mentioned range. The order of determining the phases of the business cycle is as follows:

1. Take-off (boom) - Quadrant I of the chart of The Business Cycle Study, which is characterized by positive values of the corrected indicator of the business climate and its absolute gains.
2. Recession (crisis) - Quadrant II of the chart of The Business Cycle Study, characterized by negative values of the corrected indicator of the business climate and positive values of its absolute gains.

3. Depression - Quadrant III of the chart of The Business Cycle Study, which is characterized by negative values of the corrected indicator of the business climate and its absolute gain.

4. Revival - Quadrant IV of the chart of The Business Cycle Study, characterized by positive values of the corrected indicator of the business climate and negative values of its absolute gains.

According to the classic theory, the phases of the business cycle have the following signs: 1) the takeoff is characterized by the production growth, its enhanced efficiency, revival of economic activity in different spheres, higher level of life, increased salary and other kinds of income; 2) recession (crisis) is notable for sharp but not critical decline of production or slowing rates of its increase, dropping level of salaries, rise in unemployment; 3) depression comes after 
the crisis of excessive production and is remarkable for stagnation in production, gradual liquidation of surplus commodities, high unemployment; 4) revival is characterized by the increase in effective demand and rise in employment.

The periods of phases of the business cycles for Ukraine's economy and specific sectors of food industry were determined depending on the quadrant, in which this or that point was:

- take-off (boom) - the value of the indicator is in quadrant 1: since Q 12003 till Q 2 2004; Q 12005 ; Q 1 \& 2 2006; since Q 42006 till Q 3 2007; since Q 4 2010 till Q 2 2011; since Q 32012 till Q 2 2013; Q 2 \& 32017 ;

- recession (crisis) - when the value of the indicator is in quadrant 2: Q 3\&4 2004; since Q 22005 till Q 4 2005; since Q 42007 till Q 2 2008; Q 3 2013; since Q 42017 till Q 3 2018;

- depression - the value of the indicator is in quadrant 3: Q 3 2002; since Q 32008 till Q 1 2009; Q 3\&4 2011; since Q 42013 till Q 12015 ; since Q 42018 till Q 2 2019;

- revival - the value of the indicator is in quadrant 4 : Q 4 2002; since Q 22009 till Q 2 2010; Q 1\&2 2012; since Q 22015 till Q 12017.

The summarization of the main indicators resulted in obtaining the characteristics of phases of the business cycle for Ukraine's economy (Table 1).

The results of analysis of the specificities in economy development in the phases of the business cycle demonstrate that the periods of crisis in Ukraine are accompanied with the reduction in expenses for innovations, enhanced rise in the production and consumer prices for products and, at the same time, slowdown of its consumption, conditioning the excess of supply (average gain growth $9 \%$, calculated using the data of the State Statistics Service) over demand (average gain growth $2 \%$, calculated using the data of the State Statistics Service) and became the reason of excessive production of commodities (Table 1). However, the country's economy had the highest decline in the efficiency during the phase of depression, which was manifested in slowing down GDP increase, rapid increase in the exchange rate of domestic currency and consumer prices for commodities (at a low level of salaries for the population), rapid decline of production (average decline rate $-7 \%$, calculated using the data of the State Statistics Service) and consumption (average decline rate $-10 \%$, calculated using the data of the State Statistics Service), rise in unemployment. The occurrence of recessionary-depressive state was conditioned by a considerable excess in the rate of growth of consumer prices compared to the purchasing power of the population. Here the expenses for innovations during this period increased rapidly.

At the same time, the periods of crisis and depression were accompanied with a considerable flow of capital investments (average growth rates of $17 \%$ and $25 \%$ respectively, calculated using the data of the State Statistics Service) which generally is the basis of economy development (progress). However, during the crisis periods the investments usually flew into the production ramp-up and procurement of ready equipment, machinery and software (which are not new for the market anymore), but were not directed into studies, elaboration or introduction of new production technologies.

Table 1. The specificities of Ukraine's economy development in phases of the business cycle*

\begin{tabular}{l|l|l|l|l}
\hline \multicolumn{1}{c|}{ Index } & \multicolumn{1}{c|}{ Phase of boom } & \multicolumn{1}{|c|}{ Phase of crisis } & Phase of depression & \multicolumn{1}{c}{ Phase of revival } \\
\hline GDP in actual prices & Increases & Increases rapidly & Increases slowly & Increases \\
Domestic currency rate against USD & Increases slowly & Declines slowly & Increases rapidly & Increases slowly \\
Consumer price index & Increases & Increases rapidly & Increases rapidly & Increases \\
Capital investment & Increase & Increase rapidly & Increase rapidly & Increase slowly \\
Expenses for innovations & Increase & Decline rapidly & Increase rapidly & Increase slowly \\
Production & Increases & Increases & Declines & Increases slowly \\
Consumption & Increases & Increases slowly & Declines & Increases slowly \\
Number of employed & No changes & No changes & Declines & No changes \\
Number of registered unemployed & No changes & Increases & No changes \\
Average monthly nominal wages & Increases & Increases & Increases rapidly \\
\hline
\end{tabular}

*Note: Interpretation of characteristics of phases of the cycle: no changes - average gain growth within the range of $\pm 1 \%$; increases/declines slowly - average gain growth within the range of $\pm 1 \%- \pm 5 \%$; Increases/declines - average gain growth within the range of $\pm 5 \%- \pm 10 \%$; Increases/declines rapidly - average gain growth exceeds $\pm 10 \%$. Source: original development using the data of the State Statistics Service of Ukraine. 
Thus, the criteria of efficient functioning of food industry enterprises in the phase of crisis and depression are as follows:

1) balanced volumes of supply and production;

2) accelerated increase in the volumes of investments and innovations;

3) substantiated formation of prices for products, taking into consideration both expenses and purchasing power of the population.

The determined phases of the business cycle were used to reveal the specificities of development for the main sectors of food industry (Table 2). The analysis of the model indicates that the main sectors of food industry (production of meat and meat products, milk and dairy products, bread and bakery products, sugar) had different response to the changes, caused by the cyclicality of economy. The response to lower indicators of efficiency in meat processing, milk processing and sugar production was much sharper. Their business and innovative activity corresponded to the general behavior of economic agents in the relevant phases of business cycles, and their common signs were as follows:

- in the phase of take-off (boom) - increasing volumes of production and consumption of products, stable prices, increase in investments;

- in a state of crisis - gradual decrease in the growth rate and further on - in volumes of production and capital investments, rise in consumer prices at simultaneous decrease in population's consumption;

- in a depressed state - rapid decline of production, low demand for products and rapid rise in prices for it, increased volumes of investments.

The study demonstrated that the business and innovation activity in the sector of production of bread and

Table 2. The specificities of the development of the food industry sectors during the phases of business cycles*

\begin{tabular}{|c|c|c|c|c|}
\hline Index & Phase of boom & Phase of crisis & Phase of depression & Phase of revival \\
\hline \multicolumn{5}{|c|}{ Production of meat and meat products } \\
\hline $\begin{array}{l}\text { Production } \\
\text { Consumption } \\
\text { Prices of producers } \\
\text { Consumer prices } \\
\text { Capital investment }\end{array}$ & $\begin{array}{l}\text { Increases slowly } \\
\text { Increases } \\
\text { No changes } \\
\text { Decline slowly } \\
\text { Increase slowly }\end{array}$ & $\begin{array}{l}\text { Increases } \\
\text { Declines } \\
\text { Increase slowly } \\
\text { Decline slowly } \\
\text { Decline }\end{array}$ & $\begin{array}{l}\text { Declines rapidly } \\
\text { Declines slowly } \\
\text { Increase slowly } \\
\text { Increase } \\
\text { Increase }\end{array}$ & $\begin{array}{l}\text { Increases slowly } \\
\text { Increases slowly } \\
\text { Increase } \\
\text { Increase slowly } \\
\text { Increase slowly }\end{array}$ \\
\hline \multicolumn{5}{|c|}{ Production of milk and dairy products } \\
\hline $\begin{array}{l}\text { Production } \\
\text { Consumption } \\
\text { Prices of producers } \\
\text { Consumer prices } \\
\text { Capital investment }\end{array}$ & $\begin{array}{l}\text { Increases slowly } \\
\text { Increases } \\
\text { No changes } \\
\text { No changes } \\
\text { Increase }\end{array}$ & $\begin{array}{l}\text { Increases } \\
\text { Declines } \\
\text { Increase slowly } \\
\text { Increase slowly } \\
\text { Increase slowly }\end{array}$ & $\begin{array}{l}\text { Declines } \\
\text { Declines slowly } \\
\text { Increase slowly } \\
\text { Increase slowly } \\
\text { Increase rapidly }\end{array}$ & $\begin{array}{l}\text { No changes } \\
\text { Increases slowly } \\
\text { Increase } \\
\text { Increase } \\
\text { Increase }\end{array}$ \\
\hline \multicolumn{5}{|c|}{ Production of bread and bakery products } \\
\hline $\begin{array}{l}\text { Production } \\
\text { Consumption } \\
\text { Prices of producers } \\
\text { Consumer prices } \\
\text { Capital investment }\end{array}$ & $\begin{array}{l}\text { Declines slowly } \\
\text { No changes } \\
\text { Increase slowly } \\
\text { Increase slowly } \\
\text { Increase }\end{array}$ & $\begin{array}{l}\text { Declines slowly } \\
\text { No changes } \\
\text { No changes } \\
\text { No changes } \\
\text { Increase rapidly } \\
\end{array}$ & $\begin{array}{l}\text { Declines rapidly } \\
\text { No changes } \\
\text { Increase } \\
\text { Increase rapidly } \\
\text { Decline } \\
\end{array}$ & $\begin{array}{l}\text { Declines slowly } \\
\text { Declines } \\
\text { Increase slowly } \\
\text { Decline } \\
\text { Increase } \\
\end{array}$ \\
\hline \multicolumn{5}{|c|}{ Sugar production } \\
\hline $\begin{array}{l}\text { Production } \\
\text { Consumption } \\
\text { Prices of producers } \\
\text { Consumer prices } \\
\text { Capital investment }\end{array}$ & $\begin{array}{l}\text { Increases slowly } \\
\text { Increases } \\
\text { Decline slowly } \\
\text { Decline slowly } \\
\text { Increase }\end{array}$ & $\begin{array}{l}\text { Increases } \\
\text { Declines rapidly } \\
\text { Increase } \\
\text { Increase } \\
\text { Increase slowly }\end{array}$ & $\begin{array}{l}\text { Declines } \\
\text { No changes } \\
\text { Increase rapidly } \\
\text { Increase rapidly } \\
\text { Increase rapidly }\end{array}$ & $\begin{array}{l}\text { Increases rapidly } \\
\text { Declines slowly } \\
\text { Increase slowly } \\
\text { Increase slowly } \\
\text { Decline rapidly }\end{array}$ \\
\hline
\end{tabular}

Source: original development. *Note: Interpretation of characteristics of phases of the cycle: no changes - average gain growth within the range of $\pm 1 \%$; increases/declines slowly - average gain growth within the range of $\pm 1 \%- \pm 5 \%$; increases/ declines - average gain growth within the range of $\pm 5 \%- \pm 10 \%$; increases/declines rapidly - average gain growth exceeds $\pm 10 \%$. Source: original development using the data of the State Statistics Service of Ukraine. 
bakery products differs from other sectors in the fact that it has a declining character of production in all the phases of the cycle, just with different intensity. The volume of consumption for bakery products did not change for three phases (boom, crisis and depression), and in the revival phase the consumption decreased contrary to the general tendency. It is evident that the bakery sector requires special attention to its management, in particular, regarding the re-distribution of investments between the phases of the business cycle.

Rapid rise in prices during the depression phase was notable for all the sectors of food industry and had negative impact on the volumes of commodity production.

\section{CONCLUSIONS}

It has been established that the consequences of the impact of globalization on the innovative development of the food industry in Ukraine, are as follows:

- forming the structure of domestic industrial production under the impact of the demand from the external market, where raw materials and primary processing products are in most demand;

- accelerated rise in consumer prices for food products, which does not correlate with actual income of the population;

- increase in the number of foreign companies and scales of monopolization of the food markets;

- cyclicality of economy development which conditions the loss of balance between the key indices in different spheres of economy, including -innovational development of the food industry sectors, etc.

The proposed methodological approach, based on the identified signs of the phases of the business cycle, made it possible to justify the problem periods of business and innovation activity in the food industry in the short term, as these problems significantly affect the implementation of long-term plans.

The study results demonstrate that the cyclicality is a mechanism of development of any economic system, including the food system, its coming to a new level of its functioning. It was established that the most complicated conditions for innovative development of food industry of Ukraine occurred in quarter 1 of 2015 , and the most favorable conditions were in quarter 2 of 2004 .

The assessment of the indicator of the business climate and the chart of The Business Cycle Study demonstrated that during the period from quarter 3 of 2002 till quarter 2 of 2019 the Ukrainian economy (includ- ing food industry) passed 4 business cycles, with the depression phase absent in the first of them (quarter 3 of 2002 - quarter 4 of 2008). This situation may be explained by the fact that during the period of 2002-2008 there was more favorable business climate in the country compared to 2018. This situation was manifested in the following: 1) the average annual volume of expenses for innovations in the industry (in dollar terms) during this period was three times higher than the volume of similar expenses in 2018 (USD 441.3 million); 2) average annual share of the innovation products in the general volume of the sold products of industrial enterprises in 2002-2008 exceeded the index for 2018 more than 7 times $(2008-6 \% ; 2018-0.8 \%)$; 3$)$ the share of machine building in the structure of the sold products (in 2002-2008 - on average $20 \%$ ) exceeded the share of 2018 twice (10\%) etc.

The main signs for the occurrence of the depression phase in three other business cycles are as follows: excess of the supply over demand and directing investment resources not into innovation developments and technologies, but into the ramp-up of producing traditional commodities.

Although the crisis phase had negative consequences for economy, it also led the latter to the new trajectory of development. Here the factors which had positive impact on the restorative dynamics in food industry were as follows: investments into the innovation development; introduction of domestic innovations; development of domestic machine building as a supplier of modern technical and technological equipment into the industry; deep processing of agricultural raw materials, etc.

In addition, it is absolutely important to have reasonable budget policy in the conditions of crisis, in particular, cutting the taxes during the crisis periods and increasing them during the take-off periods; decreasing the loan rates; protecting the domestic banking system and controlling the activity of banking institutions (creating institutional requirements to prevent the impact of "shadow banking sector"); preserving actual value of money; stabilizing the exchange rate for national currency; ensuring price stability; increasing the domestic demand for the main consumer goods via ensuring the purchasing power of the population and social guarantees; protecting the domestic small business from the monopolization of the domestic market, etc.

In addition to the abovementioned, the preventive measures in managing the sectors and enterprises during the crises and depressions may be as follows: creat- 
BALIAN et al.

ing stocks of raw materials for some periods of time; measures of preventing the downsizing of the workforce and keeping qualified personnel; establishing partner relations with the participants of productionsale chain with the preservation of pre-crisis proportions in income; reconstruction of the management system (stress management, measures of anti-crisis management) and other measures, conditioned by the managerial capabilities of the managers and sectorwise specificities.

The presented scientific study will serve as a basis for further scientific investigations in the sphere of cyclicality of the development of food industry, in particular, in terms of extending the methodological instruments to determine the economic cyclicality, the classification of business cycles using the methods of deep data processing, more detailed disclosure of reasons and consequences of the increase and decline in the innovation activity, the measures of state regulation on macro-, meso- and microlevels in the phases of the business cycle, etc.

This article does not contain any studies using humans and animals as study objects.

The authors declare the absence of any conflicts of interests.

This study was not financed by any specific grant from financing institutions in the state, commercial or noncommercial sectors.

\section{Вплив глобалізаційних процесів на інноваційний розвиток харчової промисловості України у фазах бізнес-циклів}

А. В. Балян ${ }^{1}$, М. П. Сичевський ${ }^{2}$, О. В. Коваленко ${ }^{2}$, Л. О. Ященко ${ }^{2}$, С. Б. Вербицький ${ }^{2}$

${ }^{1}$ Національна академія аграрних наук, вул. Михайла Омеляновича-Павленка, 9, Київ, 01010, Україна

${ }^{2}$ Інститут продовольчих ресурсів Національної академії аграрних наук України, вул. Свгена Сверстюка, 4а, Київ, 02002, Україна

e-mail: sychevskiy@ipr.net.ua; okovalenko0960@gmail. com; lud_ya@ukr.net; verb@ipr.net.ua

Однією $з$ важливих проблем розвитку харчової промисловості в Україні є вплив глобалізаційних процесів, що супроводжуються циклічністю розвитку економіки. Цикли проявляються в періодичних підйомах і спадах ділового клімату з урахуванням впливу різних факторів (зміни клімату, ризиків в сільськогосподарському виробництві, законодавчих змін та ін.), тобто коли економіка прагне знайти рівновагу. Тому виявлення коливань економічної активності і, відповідно, змін кон'юнктури ринку, що виникають як реакція на дію цілком певних, передбачуваних чинників ринкового середовища, є актуальним і необхідним. Мета. Розкрити вплив глобалізаційних процесів та економічної циклічності на інноваційний розвиток харчової промисловості України, виявити фази бізнес-циклів, визначити критерії ефективного функціонування окремих галузей харчової промисловості в періоди кризи та депресії з метою розроблення дієвих інструментів нівелювання та згладжування їх наслідків на різних рівнях управління. Методи. На основі застосування класичних та сучасних методів оцінки економічних циклів було вироблено власний методичний підхід, до обгрунтування фаз бізнес-циклу та виявлення особливостей розвитку окремих галузей харчової промисловості України (м'ясопереробної, молокопереробної, хлібопекарської, цукрової) у цих фазах. В авторському алгоритмі, на відповідних етапах дослідження, було застосовано методи: факторного аналізу для обчислення індикатора ділового клімату; згладжування динамічних рядів - для ідентифікації окремих фаз бізнес-циклу; середніх значень темпів приросту для узагальнення характеристик фаз бізнес-циклу та виявлення особливостей розвитку галузей харчової промисловості України у цих фазах. Вхідними даними для розрахунків слугували дані світової та національної статистики. Результати. Встановлено, що наслідками впливу глобалізації на розвиток харчової промисловості України $з$ початку нового тисячоліття стали: зміна галузевої структури, формування іiі під впливом зовнішнього ринку, де найбільшим попитом користується сировина та продукція первинної переробки; прискорене зростання споживчих цін на продовольчі товари, яке не корелює з реальними доходами населення; розширення масштабів монополізації ринків продовольства; незбалансованість попиту та пропозиції, що зумовлює перепади в перебігу економічних явищ, зокрема - інноваційного розвитку харчової промисловості та ін. Дослідження показало, що на розвиток окремих галузей харчової промисловості впливає циклічність розвитку національної економіки. Визначено періоди фаз бізнес-циклів для економіки України (з 2002 до середини 2019 р.) та їх вплив на діяльність харчової промисловості. Встановлено, що за цей період економіка України пройшла 4 бізнес-цикли 3 п'ятьма найбільшими спадами і піками економічної активності. Виявлено, що особливістю іiі розвитку $\epsilon$ наявність окремих бізнес-циклів, в яких відсутня фаза депресії. Висновки. Оцінкою інтенсивності розвитку галузей харчової промисловості на фазах бізнес-циклів обгрунтовано їхній сповільнений інноваційний розвиток. Основними причинами цього явища у харчовій промисловості є: незбалансованість попиту і пропозиції на товари; низька купівельна спроможність населення; спрямування значних обсягів інвестицій у нарощування обсягів виробництва, а не в інноваційний розвиток, не- 
ефективна цінова політика. Запропонований в статті методичний підхід, на основі виявлених ознак фаз бізнес-циклу, дає можливість обгрунтування проблемних періодів діяльності галузей харчової промисловості в короткостроковій перспективі, оскільки поточні проблеми суттєво впливають на реалізацію довгострокових планів. Це підтверджує доцільність застосування пропонованого методичного підходу в подальших дослідженнях.

Ключові слова: глобалізація, харчова промисловість, циклічність, бізнес-цикли, інноваційний розвиток.

\section{Влияние глобализационных процессов на инновационное развитие пищевой промышленности Украины в фазах бизнес-циклов}

А. В. Балян ${ }^{1}$, Н. П. Сычевский ${ }^{2}$, О. В. Коваленко ${ }^{2}$, Л. А. Ященко ${ }^{2}$, С. Б. Вербицкий ${ }^{2}$

${ }^{1}$ Национальная академия аграрных наук, ул. Михаила Емельяновича-Павленко, 9, Киев, 01010, Украина

${ }^{2}$ Институт продовольственных ресурсов Национальной академии аграрных наук Украины,

ул. Евгения Сверстюка, 4а, Киев, 02002, Украина

e-mail: sychevskiy@ipr.net.ua; okovalenko0960@gmail. com; lud_ya@ukr.net; verb@ipr.net.ua

Одной из важных проблем развития пищевой промышленности в Украине является влияние глобализационных процессов, сопровождающихся цикличностью развития экономики. Циклы проявляются в периодических подъемах и спадах делового климата, с учетом влияния различных факторов (изменения климата, рисков в сельскохозяйственном производстве, законодательных изменений и др.), то есть когда экономика стремится найти равновесие. Поэтому выявление колебаний экономической активности и, соответственно, изменений конъюнктуры рынка, возникающих как реакция на действие вполне определенных предполагаемых факторов рыночной среды являются актуальными и необходимыми. Цель. Раскрыть влияние глобализационных процессов и экономической цикличности на инновационное развитие пищевой промышленности Украины, выявить фазы бизнес циклов, определить критерии эффективного функционирования отдельных отраслей пищевой промышленности в периоды кризиса и депрессии с целью разработки действенных инструментов нивелирования и сглаживания их последствий на разных уровнях управления. Методы. На основе применения классических и современных методов оценки экономических циклов был выработан методический подход к обоснованию фаз бизнес-цикла и выявлению особенностей развития отдельных отраслей пищевой промышленности Украины (мясоперерабатывающей, молокоперерабатывающей, хлебопекар- ной, сахарной) в этих фазах. В авторском алгоритме, на соответствующих этапах исследования, были применены методы: факторного анализа - для вычисления индикатора делового климата; сглаживания динамических рядов - для идентификации отдельных фаз бизнес-цикла; средних значений темпов прироста для обобщения характеристик фаз бизнес-цикла и выявления особенностей развития отраслей пищевой промышленности Украины в этих фазах. Первичными данными для расчетов послужили данные мировой и национальной статистики. Результаты. Установлено, что последствиями влияния глобализации на развитие пищевой промышленности Украины с начала нового тысячелетия стали: изменение отраслевой структуры; формирования ее под влиянием внешнего рынка, где наибольшим спросом пользуется сырье и продукция первичной переработки; ускоренный рост потребительских цен на продовольственные товары, который не коррелирует с реальными доходами населения; расширение масштабов монополизации рынков продовольствия; несбалансированность спроса и предложения, что приводит к перепадам в развитии экономических явлений, в частности - в инновационном развитии пищевой промышленности и др. Исследование показало, что на развитие отдельных отраслей пищевой промышленности влияет цикличность развития национальной экономики. Определены периоды фаз бизнесциклов для экономики Украины (с 2002 до середины 2019) и их влияние на деятельность пищевой промышленности. Установлено, что за этот период экономика Украины прошла 4 бизнес-цикла с пятью крупнейшими спадами и пиками экономической активности. Выявлено, что особенностью ее развития является наличие отдельных бизнес-циклов, в которых отсутствует фаза депрессии. Выводы. Оценка интенсивности развития отраслей пищевой промышленности на фазах бизнес-циклов способствовала обоснованию их замедленного инновационного развития. Основными причинами этого явления в пищевой промышленности являются: несбалансированность спроса и предложения на товары; низкая покупательная способность населения; вложение значительных объемов инвестиций в наращивание объемов производства, а не в инновационное развитие, неэффективная ценовая политика. Предложенный в статье методический подход, на основе выявленных признаков фаз бизнес-цикла, дает возможность обоснования проблемных периодов деятельности отраслей пищевой промышленности в краткосрочной перспективе, поскольку текущие проблемы существенно влияют на реализацию долгосрочных планов. Это подтверждает целесообразность применения предлагаемого методического подхода в дальнейших исследованиях.

Ключевые слова: глобализация, пищевая промышленность, цикличность, бизнес-циклы, инновационное развитие. 


\section{REFERENCES}

1. Phelps PS. What is wrong with the West's economies? Homo Oeconomicus. 2016;33(1):3-10. http://link.springer.com/10.1007/s41412-016-0006-3.

2. Fischer S. Longer-Term Challenges for the US Economy. New York, New York, November 21, 2016.

3. Kovalenko O, Verbytskyi $S$, Lysenko $H$. Evaluation of effectiveness of innovative modernization of food industry. The Scientific Journal of Cahul State University "Bogdan Petriceicu Hasdeu" Economic and Engineering Studies. 2017;2(2):50-6.

4. Ciliberti S, Bröring S, Martino G. Drivers of innovation in the European food industry: evidences from the Community Innovation Survey. Int. J. Food System. Dynamics. 2015;6(3):175-90. doi: 10.18461/1869-6945-15.

5. Kavanagh $G$, Henchion $M, M c$ Carthy $M$, McCarthy $S$, Williams $G$. Technological Innovation - A Route Towards Sustainability in the Irish Food Industry. Int. J. Food System. Dynamics. 2012;3(1):35-49.

6. Gagalyuk T, Hanf JH, Hingley M. Firm and whole chain success: network management in the Ukrainian food industry. J. Chain Network Sci. 2013;13(1):47-70. doi: 10.3920/JCNS2013.x226.

7. Jaime de Pablo Valenciano, Miguel Angel Giacinti Battistuzzi, Tomás Garcia Azcaráte. Chile-EU Trade Agreement: What Can We Learn from Trade Statistics? Int. J. Food System Dynamics. 2015;6(1):12-23. doi: https://doi.org/10.18461/ijfsd.v6i1.612.

8. Arthur F Burns, Wesley C Mitchell. Dating Specific and Business Cycles. National Bureau of Economic Research, 1946:56-114. URL: https://www.nber.org/ chapters/c2983.pdf

9. Pugachova $M V$. New instruments of evaluating the business cycle. Statistics of Ukraine. 2012;58(3):35-43. [in Ukrainian]

10. Kondratiev ND, Opearin DI. Large cycles of conjuncture. M., 1928:287 p. [in Russian]

11. Rostow W.W. Why the Poor Get Richer and the Rich Slow Down: Essays in the Marshallian long period, 1980:394 p.

12. Pestova A. Predicting Turning Points of the Business Cycle: Do Financial Sector Variables Help? Voprosy Ekonomiki.2013;(7):63-81.doi:https://doi.org/10.32609/ 0042-8736-2013-7-63-81.

13. Pieter Vlag, Geert Bruinooge, Kees Zeelenberg, Symon
Algera, Ben van Cleef. Tracing and explaining business cycles, a factsheet with rapid estimates. Statistics Netherlands, 2009:13.

14. Minegishi S, Thiel D. System dynamics modeling and simulation of a particular food supply chain. Simulat. Pract. Theor. 2000;8(5):321-39. doi: 10.1016/s09284869(00)00026-4.

15. Stave KA, Kopainsky B. A system dynamics approach for examining mechanisms and pathways of food supply vulnerability. J. Environ. Stud. Sci. 2015;5(3):321-36. http://dx.doi.org/10.1007/s13412-015-0289-x.

16. Olafsdottir AH, Gudbrandsdottir I, Sverdrup HU, Bogason SG, Olafsdottir G, Stefansson G. System Dynamics Modelling and System Analysis Applied in Complex Research Projects - the Case of Valumics. J. Food Syst. Dynam. 2018;9(5):409-18. doi: https://doi. org/10.18461/ijfsd.v9i5.953.

17. Bazhal Iurii. The Theory of Economic Development of J.A. Schumpeter: Key Features. National University of Kyiv-Mohyla Academy, 2016:2-16.

18. Kuepper Justin. What Will Be the World's Largest Economies By 2050? Preparing Investors for Global Changes. 2019. URL: https://www.thebalance.com/largest-world-economies-in-2050-4153858.

19. Farkas B. Market economies of the Western Balkans compared to the Central and Eastern European model of capitalism. Croatian Economic Survey. 2017;19(1):5-36. doi: 10.15179/ces.19.1.1.

20. Oilseeds: World Markets and Trade. USDA. 2019. Available at: https://downloads.usda.library.cornell.edu/ usda-esmis/files/tx31 qh68h/2v23w681b/nc5811169/ oilseeds.pdf.

21. Databases of the Agency in developing the infrastructure of the stock market of Ukraine. Public joint-stock company Agroholding Avangard. URL: https://smida. gov.ua/db/emitent/00851519.

22. The joint harmonized EU program of business and consumer surveys: user guide. European Commission Directorate-General for Economic and Financial Affairs. 2016. URL: http://ec.europa.eu/economy_finance/db_ indicators/surveys/documents/bcs_user_guide_en.pdf

23. Nasledov A. IBM SPSS Statistics 20 and AMOS: professional statistical analysis of the data. StP: Piter, 2013:416 p. 